\title{
Immune Thrombotic Thrombocytopenic Purpura in a Patient with Suspected COVID-19: Hydroxychloroquine Culprit or Just Happenstance?
}

\author{
COVID-19 Şüpheli Bir Hastada Immün Trombotik Trombositopenik Purpura: Hidroksiklorokin \\ Suçlu mu Yoksa Sadece Rastlantı mı?
}

Tajamul H. Mir

Khyber Medical Institute Srinagar, Department of Nephrology and Lupus/Vasculitis Centre, Srinagar, India

\section{To the Editor,}

I read with great interest the recently published letter to the editor by Arıkan et al. [1] about hydroxychloroquine (HCO)-associated thrombotic thrombocytopenic purpura (TTP) together with some queries raised by Sookaromdee and Wiwanitkit and the original authors' reply $[1,2]$. There are some pertinent points to note. First and foremost, $\mathrm{HCQ}$-induced TTP is an extremely rare but nevertheless recognized entity with only a few cases reported in the literature, which have not been thoroughly evaluated. Most of the data regarding this complication have been extrapolated against the background of HCQ's parent compound, quinine. Quinine-induced and presumably $\mathrm{HCQ}$-induced TTP is characterized by generation of antiplatelet antibodies, which cross-react with the endothelium and cause TT. However, typical drug-induced TाP, including quinine-induced TTP, is not associated with a critical drop in ADAMTS13 levels or with the presence of an ADAMTS13 inhibitor, but the patient presented by Arıkan et al. had both. This is an important differentiating feature of quinine-induced TTP from immune TTP (iTTP) and it calls into question the diagnosis made by Arıkan et al. [1] or even suggests iTP after $\mathrm{HCO}$ as a novel complication [3]. I would not straight away repudiate the observation made by Arıkan et al. [1] because, first of all, there is a definite temporal profile that links the medicine with iTTP, and, furthermore, some drugs like the thienopyridine group of antiplatelets have been associated with classic ITTP leading to a critical drop in ADAMTS13 levels and the presence of an inhibitor [4]. At least five cases of thrombotic microangiopathy of iTTP/ HUS (hemolytic uremic syndrome) in coronavirus disease-19 (COVID-19) have been reported in the literature with an obvious temporal relation between $\mathrm{HCO}$ and the development of iTTP, which seems to have been ignored by most authors in light of COVID-19 infection and everything being attributed to this novel virus $[5,6,7,8]$. It needs to be emphasized that quinine-induced thrombotic microangiopathy can occur hours, days, or months after exposure to the drug and HCO has a very long elimination half-life of 40 days after a single dose. The typical COVID-19-induced TTP-like illness is secondary to diffuse endothelial damage secondary to virusinduced endotheliitis further aggravated by complement overactivity, causing an over-spilling of von Willebrand factor (vWF) from the damaged endothelial network overwhelming the ADAMTS13 protease and producing the relative ADAMTS deficiency typically seen as an ADAMTS13/vWF ratio of $<10$, but without a critical drop in ADAMTS13 levels and in the absence of a circulating ADAMTS inhibitor [9]. Nevertheless, some cases of classic iTTP have occurred in association with COVID-19 infection, possibly due to some novel mechanism triggered by the virus or maybe the unmasking of a latent disease with the virus possibly acting as a second hit. Differentiating primary from secondary thrombotic microangiopathy is not always easy since many genetic or even acquired variants could be clinically silent, becoming manifest later in life following a second hit such as an infection, drug, surgical stress, or pregnancy. In the case presented by Arıkan et al. [1], I feel that at least immunoglobulin $\mathrm{G}$ anti-COVID antibodies should have been examined and, if possible, novel in vitro $\mathrm{HCO}$ sensitization testing should be performed as well [10]. Although re-exposure to the drug could easily solve the diagnostic dilemma, it would be absolutely unethical and risky since the second exposure could be more devastating if the drug were in fact the culprit. The initial illness in the patient could have been any trivial infection or maybe a mild COVID case (though not documented). I am sure the authors must have thoroughly evaluated the patient for other mimickers and ruled them out, and systemic lupus erythematosus seems very unlikely. The role of HCQ in causing iTTP in the given case cannot be absolutely ruled out.

Keywords: COVID-19-induced iTP, Hydoxychloroquineinduced TTP, ADAMTS13, Von Willebrand factor, Thrombotic microangiopathy 
Anahtar Sözcükler: COVID-19 ilişkili iTT, Hidroksiklorokin ilişkili TTP, ADAMTS-13, Von Willebrand faktör, Trombotik mikroanjiyopati

Financial Disclosure: The author declared that this study received no financial support.

\section{References}

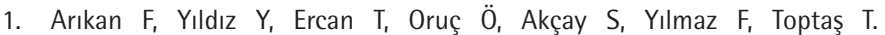
Hydroxychloroquine-associated thrombotic thrombocytopenic purpura. Turk J Hematol 2020;37:302-304.

2. Sookaromdee P, Wiwanitkit V. Hydroxychloroquine, TTP, COVID-19 and SLE. Turk J Hematol 2021;38:99-100.

3. Page EE, Little DJ, Vesely SK, George JN. Quinine-induced thrombotic microangiopathy a report of 19 patients. Am J Kidney Dis 2017;70:686-695.

4. Zakarija A, Kwaan HC, Moake JL, Bandarenko N, Pandey DK, McKoy JM, Yarnold PR, Raisch DW, Winters JL, Raife TJ, Cursio JF, Luu TH, Richey EA, Fisher MJ, Ortel TL, Tallman MS, Zheng XL, Matsumoto M, Fujimura Y, Bennett CL. Ticlopidine and clopidogrel-associated thrombotic thrombocytopenic purpura (TTP): review of clinical, laboratory, epidemiological, and pharmacovigilance findings (1989-2008). Kidney Int Suppl 2009;112:20-24.

5. Albiol N, Awol R, Martino R. Autoimmune thrombotic thrombocytopenic purpura (TTP) associated with COVID-19. Ann Hematol 2020;99:1673-1674.

6. Hindilerden F, Yonal-Hindilerden I, Akar E, Kart-Yasar K. Covid-19 associated autoimmune thrombotic thrombocytopenic purpura: Report of a case. Thromb Res 2020;195:136-138

7. Capecchi M, Mocellin C, Abbruzzese C, Mancini I, Prati D, Peyvandi F. Dramatic presentation of acquired thombotic thrombocytopenic purpura associated with COVID-19. Haematologica 2020;105:540.

8. Al-Ansari RY, Bakkar M, Abdalla L, Sewify K. Critical care COVID-19 patient with a picture of thrombotic thrombocytopenic purpura. Eur J Case Rep Intern Med 2020;7:002143.

9. Galbiati V, Papale A, Kummer E, Corsini E. In vitro models to evaluate druginduced hypersensitivity: Potential test based on activation of dendritic cells. Front Pharmacol 2016;7:204.

10. Martinelli $N$, Montagnana $M$, Pizzolo $F$, Friso $S$, Salvagno GL, Forni GL, Gianesin B, Morandi M, Lunardi C, Lippi G, Polati E, Olivieri O, De Franceschi L. A relative ADAMTS13 deficiency supports the presence of secondary microangiopathy in COVID 19. Thromb Res 2020;193;170-172.

\section{REPLY FROM THE AUTHORS}

\section{To the Editor,}

We thank our colleague for his interest and excellent comments.

We totally agree that the case that we reported is not a typical case of quinine-induced thrombotic thrombocytopenic purpura (TTP) [1]. As Mir emphasized, a significant decrease in the activity of ADAMTS13 or the presence of inhibitors is not an expected finding in quinine-associated TT. However, infections as well as drugs can act as a second hit in some patients with silent genetic or acquired TTP variants, as Mir stated. Furthermore, HCO could act as a second hit in the patient, or HCO could also cause TP with low ADAMTS13 activity in some patients, similar to other drugs such as the thienopyridine group of antiplatelet drugs. That is why we assume that this was a case of antibodymediated TTP, possibly induced by HCO.

There are some reported cases of severe acute respiratory syndrome causing coronavirus- 2 presenting with TTP in the literature. In most of these cases, lung CT showed significant infiltration with positive polymerase chain reaction tests by nasopharyngeal swab [2] or positivity for specific immunoglobulin $(\mathrm{Ig}) \mathrm{G}$ [3]. Our limitation was that specific IgG could not be determined serologically. In addition, there were no laboratory abnormalities that suggested coronavirus disease-19 (COVID-19), such as lymphopenia or high serum ferritin or fibrinogen. We also excluded cardiovascular, autoimmune, and malignant diseases. After the patient was discharged, we tried to contact the patient, but we learned that this individual had moved to another city. Interestingly, we were informed that the patient was diagnosed with COVID-19 by rapid testing and specific clinical findings in a different hospital 4 months later. At that time, the patient was not using $\mathrm{HCO}$. The patient improved without significant sequelae. Furthermore, we could not determine specific IgG levels related to the illness complicated with TTP during the first hospitalization.

HCO has some well-known hematological side effects including anemia, thrombocytopenia, agranulocytosis, leukopenia, and aplastic anemia. There are two case reports from before the COVID-19 pandemic in the literature in terms of possible HCQrelated $\Pi T$, but these relations were suspicious because these patients had respective medical histories of systemic lupus erythematosus and rheumatoid arthritis $[4,5]$.

In conclusion, it is not possible to confidently insist that HCQ has a definite role in the etiology of thrombotic microangiopathy, but our observation should be kept in mind as HCO might be associated with TTP.

Fatma Arıkan, Yasin Yıldız, Tarık Ercan, Özen Oruç, Seçkin Akçay, Fergun Yılmaz, Tayfur Toptaş, Tülin Tuğlular 


\section{References}

1. Arıkan F, Yıldız Y, Ercan T, Oruç Ö, Akçay S, Yılmaz F, Toptaş T, Tuğlular T. Hydroxychloroquine-associated thrombotic thrombocytopenic purpura. Turk J Hematol 2020;37:302-304.

2. Hindilerden $F$, Yonal-Hindilerden I, Akar E, Kart-Yasar K. CoVID-19 associated autoimmune thrombotic thrombocytopenic purpura: report of a case. Thromb Res 2020;195:136-138.

3. Capecchi M, Mocellin C, Abbruzzese C, Mancini I, Prati D, Peyvandi F. Dramatic presentation of acquired thombotic thrombocytopenic purpura associated with COVID-19. Haematologica 2020;105:e540.
4. Fromm LM. Suspected hydroxychloroquine-induced thrombotic thrombocytopaenic purpura. J Pharm Pract Res 2018;48:72-75.

5. Mar N, Mendoza Ladd A. Acquired thrombotic thrombocytopenic purpura: puzzles, curiosities and conundrums. J Thromb Thrombolysis 2011;31:119121.

6. Naranjo CA, Busto U, Sellers EM, Sandor P, Ruiz I, Roberts EA, Janecek E, Domecq C, Greenblatt DJ. A method for estimating the probability of adverse drug reactions. Clin Pharmacol Ther 1981;30:239-245.

\title{
Antithrombin, COVID-19, and Fresh Frozen Plasma Treatment
} Antitrombin, COVID-19 ve Taze Dondurulmuş Plazma Tedavisi

\author{
(D) Rujitttika Mungmungpuntipantip1, (1) Viroj Wiwanitkit2 \\ 1 Private Academic Consultant, Bangkok, Thailand \\ ${ }^{2}$ Honorary Professor, Dr DY Patil University, Pune, India
}

\section{To the Editor,}

We found the article entitled "Prognostic value of antithrombin levels in COVID-19 patients and impact of fresh frozen plasma treatment: a retrospective study" very interesting [1]. Considering antithrombin (AT) levels and fresh frozen plasma (FFP) in these patients, Anaklı et al. [1] concluded that "AT activity could be used as a prognostic marker for survival and organ failure in COVID-19-associated ARDS patients. AT supplementation therapy with FFP in patients with COVID-19-induced hypercoagulopathy may improve thrombosis prophylaxis and thus have an impact on survival" [1]. Indeed, plasma therapy is a widely discussed alternative option for management of severe coronavirus disease-19 (COVID-19). Some medical scientists have proposed the usefulness of non-convalescent plasma therapy. In a recent report, Bajpai et al. [2] found that the median improvement in $\mathrm{PaO} 2 / \mathrm{FiO}_{2}$ in COVID-19 patients treated with non-convalescent plasma was significantly superior to results of FFP at 48 hours. Additionally, an important consideration for any kind of plasma therapy is the safety. The major consideration is possible pathogenic contamination in plasma [3]. Finally, the exact pathomechanism of COVID-19-related coagulopathy is not well clarified but it is believed to be an immunopathological process [4]. The use of FFP therapy is not direct management for the underlying immunological problem; a more appropriate management might be plasma exchange therapy [5].

Keywords: Antithrombin, COVID-19, Fresh frozen plasma

Anahtar Sözcükler: Antitrombin, COVID-19, Taze dondurulmuş plazma

\section{Ethics}

Informed Consent: Informed consent is not required (no human/animal involvement).

\section{Authorship Contributions}

Concept: R.M., V.W.; Design: R.M., V.W.; Data Collection or Processing: R.M., V.W.; Analysis or Interpretation: R.M., V.W.; Literature Search: R.M., V.W.; Writing: R.M., V.W.

Conflict of Interest: No conflict of interest was declared by the authors.

Financial Disclosure: The authors declared that this study received no financial support.

\section{References}

1. Anaklı I, Ergin Özcan P, Polat Ö, Orhun G, Alay GH, Tuna V, Çeliksoy E, Kılıc M, Mercan M, Ali A, Beşışık S, Esen F. Prognostic value of antithrombin levels in COVID-19 patients and impact of fresh frozen plasma treatment: a retrospective study. Turk J Hematol 2021;38:15-21.

2. Bajpai M, Kumar $S$, Maheshwari $A$, Chhabra $K$, Kale $P$, Gupta $A$, Narayanan A, Gupta E, Trehanpati N, Bihari C, Agarwal R, Gupta K, Gupta UK, Bhardwaj A, Kumar G, Islam M, Singh R, Yadav P, Maiwall R, Sarin SK. Efficacy of convalescent plasma therapy compared to fresh frozen plasma in severely ill COVID-19 patients: a pilot randomized controlled trial. medRxiv Preprints. Available at https://doi.org/10.1101/2020.10.25.20219337.

3. Joob B, Wiwanitkit V. Convalescent plasma and covid-19 treatment. Minerva Med (in press).

4. Iba T, Levy JH, Levi M, Thachil J. Coagulopathy in COVID-19. J Thromb Haemost 2020;18:2103-2109.

5. Tabibi S, Tabibi T, Conic RRZ, Banisaeed N, Streiff MB. Therapeutic plasma exchange: a potential management strategy for critically ill COVID-19 patients. J Intensive Care Med 2020;35:827-835. 